\title{
Is weak CD4+ gain in the course of suppressive combination antiretroviral therapy for HIV infection a current clinical challenge? A case report and brief review of the literature
}

\author{
Camilla Tincati ${ }^{*}$ (D), Esther Merlini, Antonella d'Arminio Monforte and Giulia Marchetti
}

\begin{abstract}
Background: Individuals lacking immune recovery during suppressive CART will still represent a clinical issue in the years to come, given the high proportion of HIV-infected subjects introducing therapy late in the course of disease. Understanding the mechanisms underlying poor CD4+ T-cell gain is crucial for the correct clinical management of individuals in this context.

Case presentation: An HIV-infected subject with poor CD4+ T-cell gain in the course of suppressive antiretroviral therapy was extensively investigated to identify the mechanisms behind inadequate CD4+ reconstitution. In particular, we studied the phenotype of circulating T-cells, interleukin-7 signaling in peripheral blood and bone marrow, gut function and microbial translocation markers as well as the composition of the faecal microbiota. Numerous therapeutic interventions ranging from antiretroviral therapy intensification to immunotherapy and anti-hepatitis $C$ virus treatment were also employed in order to target the possible causes of poor immune-recovery.

Conclusions: Poor CD4+ T-cell gain on suppressive antiretroviral therapy is multifactorial and thus represents a clinical challenge. Clinicians should investigate subjects' immune profile as well as possible causes of chronic antigenic stimulation for the administration of the most appropriate therapeutic strategies in this setting.
\end{abstract}

Keywords: CD4+ recovery, T-cell activation, IL-7, Microbial translocation, Microbiota

\section{Background}

A low CD4+ T-cell nadir upon combination Antiretroviral Therapy (cART) introduction in Human Immunedeficiency Virus (HIV) infection is linked to weak CD4+ T-cell gain [1], exposing subjects to the increased risk of clinical events [2]. Current guidelines recommend initiation of treatment early in the course of disease [3, 4], yet data from numerous study cohorts point to the steadiness of late diagnosis of HIV and thus cART start in up to $50 \%$ of infected subjects [5]. In line with these observations, it is

\footnotetext{
*Correspondence: camilla.tincati@unimi.it

Presented in part: 14th European AIDS Conference, Brussels, Belgium,

October 2013

Department of Health Sciences, Clinic of Infectious Diseases and Tropical Medicine, ASST Santi Paolo e Carlo, University of Milan, San Paolo Hospital, Via di Rudinì 8, 20142 Milan, Italy
}

(c) The Author(s). 2018 Open Access This article is distributed under the terms of the Creative Commons Attribution 4.0 International License (http://creativecommons.org/licenses/by/4.0/), which permits unrestricted use, distribution, and reproduction in any medium, provided you give appropriate credit to the original author(s) and the source, provide a link to the Creative Commons license, and indicate if changes were made. The Creative Commons Public Domain Dedication waiver (http://creativecommons.org/publicdomain/zero/1.0/) applies to the data made available in this article, unless otherwise stated. 
was previous intravenous drug use. Nadir CD4+ T-cell count was $26 / \mu \mathrm{L}$. Hepatitis C Virus (HCV) co-infection was present (genotype 1a) and cytomegalovirus (CMV) serology was positive. No opportunistic infections were diagnosed at the time of HIV testing.

cART was initiated with zidovudine, lamivudine and indinavir/ritonavir which was changed to tenofovir, lamivudine and lopinavir/ritonavir in 2004. Despite rapid virological suppression, poor immune recovery was observed with CD4+ T-cell counts constantly below the $200 / \mu \mathrm{L}$ threshold (Fig. 1a) and impaired CD4+/CD8+ T-cell ratio (i.e. lower than 1 [6]; Fig. 1b).

A low CD4+ T-cell count at the start of cART has been associated with clinical progression $[2,7]$ and hampered immune-reconstitution (reviewed in $[8]$; $[9,10]$ ); of note, a low CD4+ T-cell nadir has also been shown to mirror the complex alterations of peripheral T-cell homeostasis in HIV infection, ranging from the impairment of lymphocyte maturation and function to increases in T-cell activation, death and T-regulatory cell (Treg) activity, which may not be reverted by treatment [9-20]. In accordance with these findings also a low CD4/CD8 T-cell ratio has been associated with skewed immune functions [21, 22] and increased clinical risk [6].

In 2001 the patient agreed to undergo immune-adjuvant interleukin-2 (IL-2) therapy, which at the time was being explored as a possible alternative therapeutic strategy to cART alone, given its ability to induce CD4+ T-cell increases and restore $\mathrm{CD} 4+\mathrm{T}$-specific responses to both recall and HIV antigens [23]. Three cycles of IL-2 were administered subcutaneously ( 1 cycle: $3 \times 10^{6}$ IU qd, days 1-5 and 8-12) for an overall duration of 3 months. Immune-therapy accounted for transitory increases in CD4+ T-cell counts that were not, however, sustained after the interruption of IL-2 cycles (Fig. 1a, b). Furthermore, the subject was diagnosed with cutaneous VZV reactivation shortly after immune-therapy. In this respect, despite the undeniable immunological effects of adjuvant IL-2 in subjects with poor CD4+ recovery on cART [24], this strategy was abandoned for the treatment of HIV infection, given it failed to provide clinical benefit compared to antiretrovirals alone [25]. Rather, it accounted for a higher relative risk of progression to AIDS in subjects with greatest $\mathrm{CD} 4+$ expansion [25], finding that was linked to a sustained increase in Treg cells [26], pointing to a major pathogenic role of this subset in the clinical outcome of treated HIV disease.

Inefficient $\mathrm{CD} 4+\mathrm{T}$-cell gain during treatment has been linked to failure in de novo $\mathrm{CD} 4+\mathrm{T}$-cell production. In this respect, impaired thymic $[27,28]$ and bone marrow function [29-31] alongside fibrosis of secondary lymphoid organs [32, 33], may represent possible pathogenic mechanisms underlying poor $\mathrm{CD} 4+$ output. A bone marrow aspirate highlighting hypo-cellularity, matrix fibrosis as well as severe dysplasia of myeloid, erythroid and platelet precursors was performed in 2006, while inconclusive results were obtained from the study of thymic function through the measurement of T-Cell Receptor Excision Circles (TREC; not shown). Given the role played by IL-7 in thymopoiesis as well as in the proliferation and survival of peripheral cells through its interaction with the IL-7 Receptor (IL-7R) on thymocytes, T-cells and bone marrow macrophages [34], we decided to investigate the IL-7/IL$7 \mathrm{R}$ system in the study patient.

Compared to uninfected controls described elsewhere [30], the subject displayed lower IL-7 plasma levels (Fig. 1c), decreased circulating IL-7R $\alpha$ (CD127)-expressing CD4+ (Fig. 1d) and IL-7R $\alpha$ production in Peripheral Blood Mononuclear Cells (PBMCs) (Fig. 1e). In sharp contrast with what observed in the periphery, in the patient's bone marrow we found increased levels and production of IL-7 (Fig. 1f, g) as well as heightened IL-7R $\alpha$ expression in Bone Marrow Mononuclear Cells (Fig. 1h). Further, lower pSTAT5- (Fig. 1i) and Bcl-2-positive CD4+ T-cells (Fig. 1j) were detected following in vitro IL-7 stimulation of the patient's PBMCs. While promising results have been produced following the use of adjuvant therapy with IL-7 in subjects with poor CD4+ T-cell recovery $[35,36]$, our findings warrant careful investigation of the possible reasons behind IL-7 administration failure in this setting [36], given that dysfunctional IL-7R signalling may feature discordant subjects [30,37].

Excessive peripheral CD4+ T-cell destruction may represent another cause of hampered immune response on cART and may be due to several features strictly linked to each other: T-cell activation, ongoing viral replication/HIV persistence and chronic antigenic stimulation. In particular, aberrant T-cell activation leading to increased cell death has been constantly associated with discordant immune responses to therapy [16-18, 28, 38] and its multifactorial pathogenesis appears to be related to productive/latent HIV infection, the presence of copathogens (HCV, CMV) and microbial translocation.

Given that stable levels of CD8+ T-cell activation were observed over the years (Fig. 1k), in 2011 we decided to expand our knowledge on the subjects' T-cell homeostasis by performing a thorough investigation of the CD4+ lymphocyte maturation phenotype. For this purpose, HIV-uninfected individuals were consecutively enrolled as a control group $(n=16$; median age 31 years, IQR 28-35; female sex 69\%; HCV co-infection $0 \%$ ) for laboratory experiments. Our analysis revealed lower frequencies of naïve (Fig. 1l) and central memory cells (Fig. $1 \mathrm{~m}$ ) as well as higher $\mathrm{CD} 4+$ effector memory (Fig. 1n) and terminally differentiated lymphocytes (Fig. 1o) compared to controls, thus pointing to persistent skewing of T-cell homeostasis despite long-term virological suppression, immunotherapy and cART intensification (see below). 

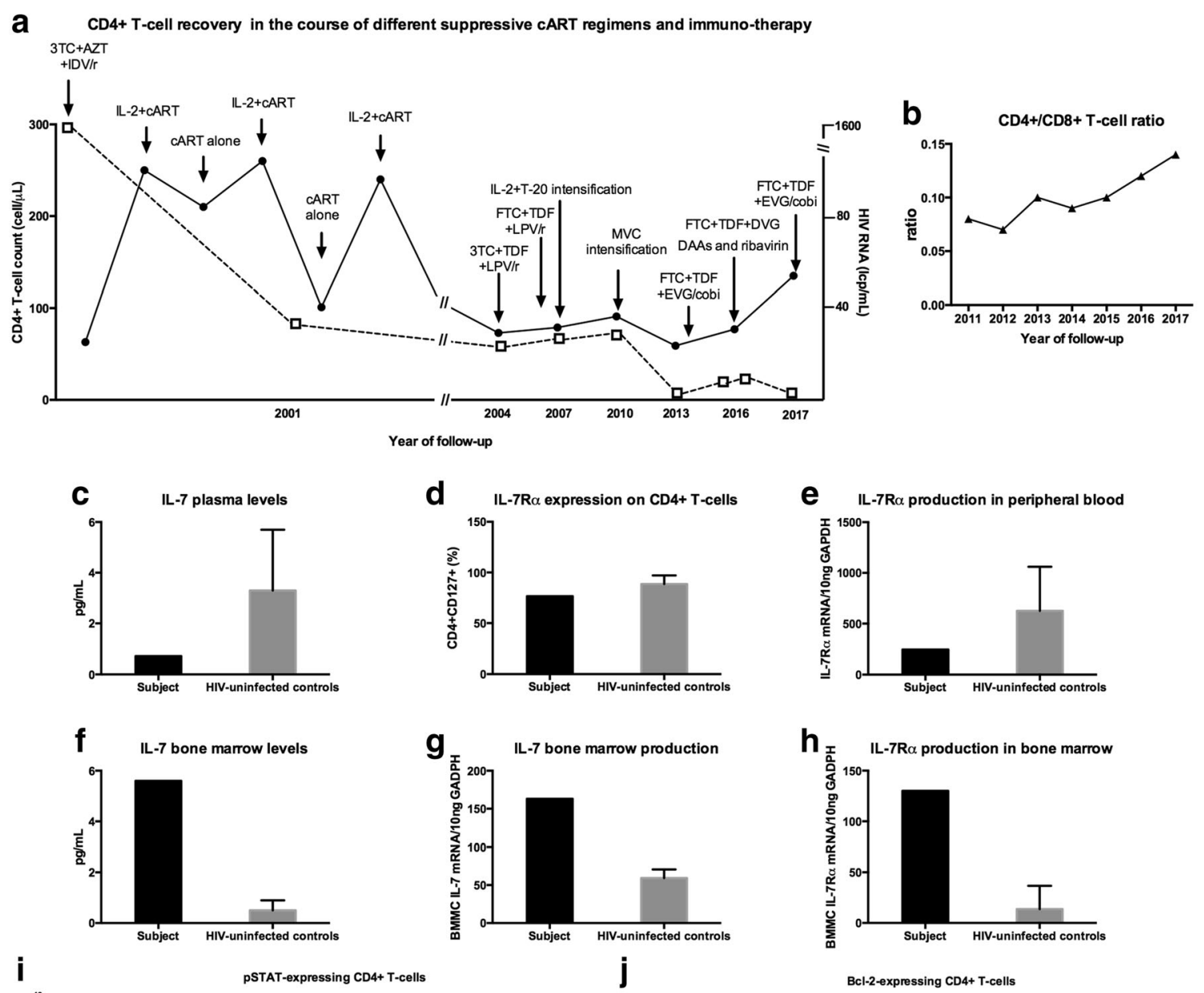

j
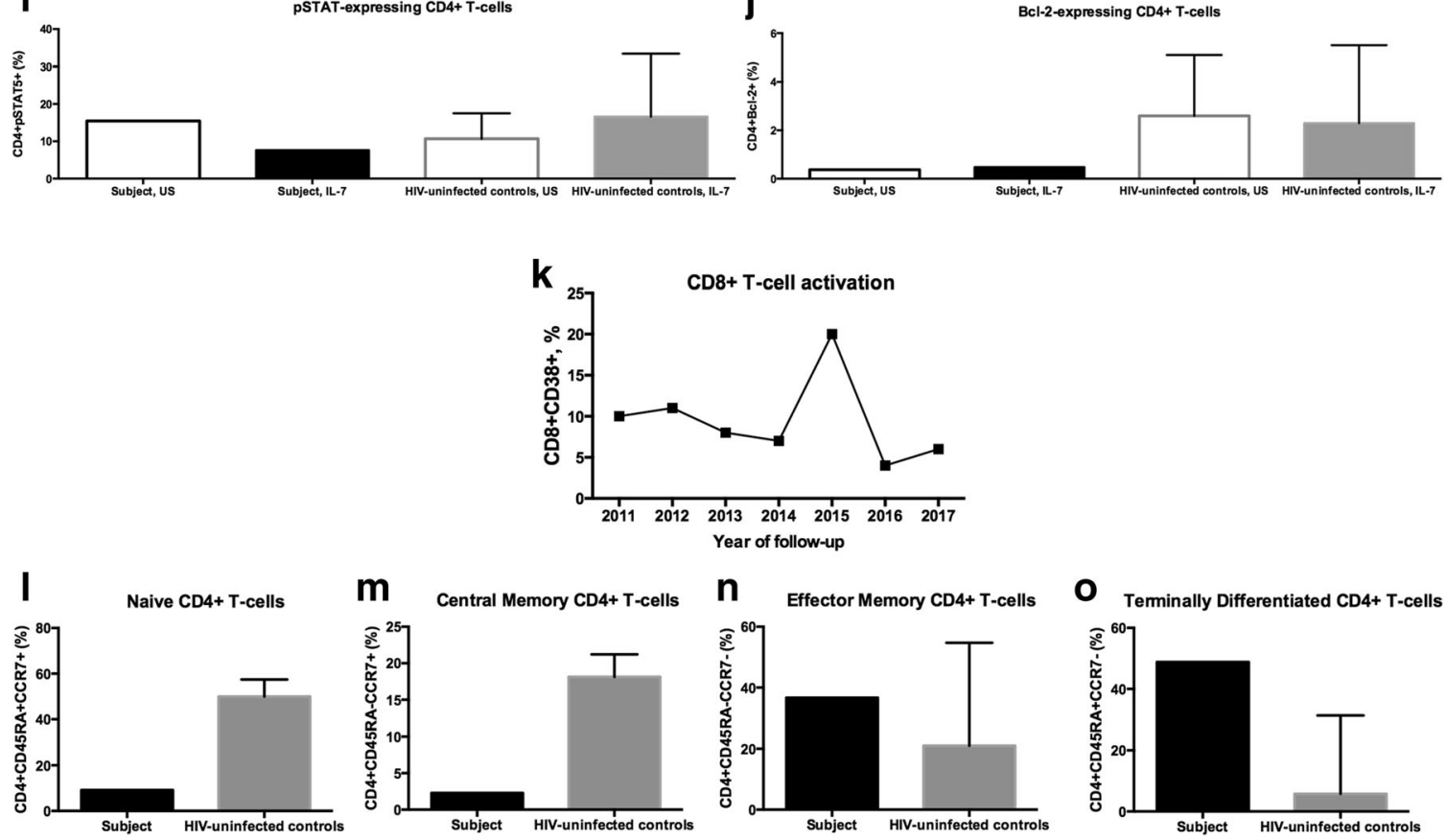

Fig. 1 (See legend on next page.) 


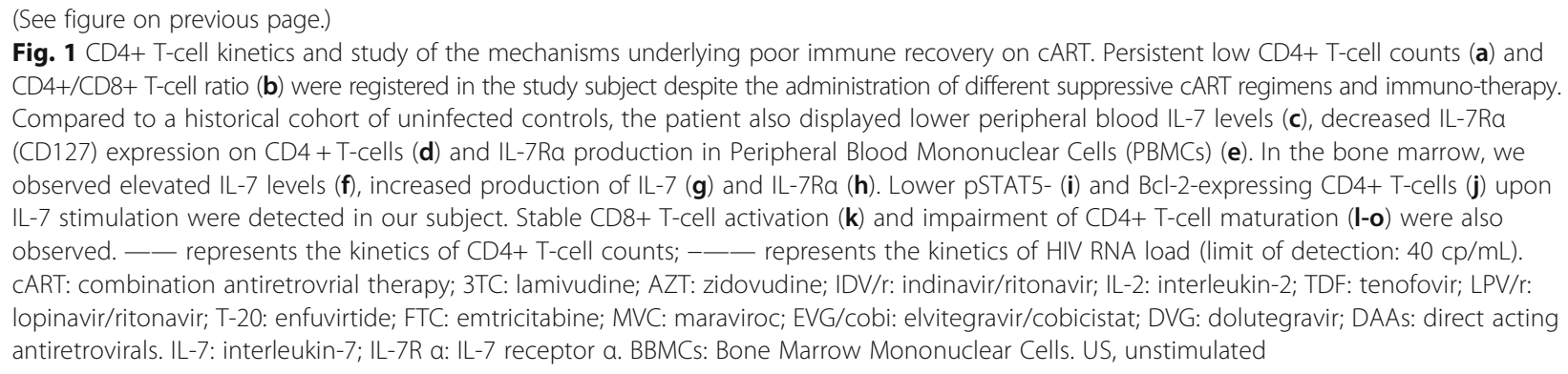

Data on the role of ongoing viral replication and increased reservoirs as a cause of immune activation and poor immune recovery in course of suppressive cART have been inconclusive, with proof of a relationship between such features in some studies [28, 39-41] and not in others $[15,39,42-44]$. Despite full virological suppression and no history of viral blips (Fig. 1a), in order to counteract the possible effects of persistent HIV replication below the limit of detection, in 2007 our patient underwent cART intensification with enfuvirtide in combination with additional 3 cycles of IL-2 adjuvant therapy, which did not lead to prolonged increases in CD4+ T-cell numbers (Fig. 1a). cART intensification was also carried out 4 years later with maraviroc which did not account for changes in CD4+ recovery (Fig. 1a, b), similarly to what observed in various studies evaluating the role of the CCR5-coreceptor inhibitor in subjects with discordant responses to cART [45-48], and may be due to the marginal impact of this molecule on T-cell activation in this setting [45-48]. Overall, intensification strategies with different classes of antiretrovirals have lead to modest T-cell gains [45-52] and produced controversial results regarding T-cell homeostasis [45, 46, 48, 50, 51, 53-57] and measures of HIV low level-replication/persistence [49, 51-56, 58-61]. Of note, in more recent years (2013-ongoing) no replication below the limit of detection $(40 \mathrm{cp} / \mathrm{mL})$ was measured in our subject, with the exception of two consecutive values, $11 \mathrm{cp} / \mathrm{mL}$ and $14 \mathrm{cp} / \mathrm{mL}$, in 2016.

HIV/CMV co-infection has been described as an additional cause of discordant immune responses to cART [62], disturbing T-cell homeostasis [63, 64]. As mentioned above, the study subject displayed serologic positivity for previous CMV infection. Although the precise role of CMV reactivation in this setting is a matter of controversy [64, 65], valganciclovir administration was shown to suppress CMV DNA levels and lower T-cell activation levels [65]. Also HCV co-infection has been widely described as a factor contributing to impaired CD4+ T-cell recovery [66] and immune skewing in HIV disease $[67,68]$. Paucity of data exists on the role of $\mathrm{HCV}$ clearance in influencing the course of CD4+ T-cell counts in subjects on long-term cART [69], however, treatment of HCV infection may have a beneficial effect on other determinants of discordant immune responses, i.e. T-cell activation [70] and liver fibrosis [69].

The patient showed mild progression in terms of $\mathrm{HCV}$-related liver disease over the years and agreed to start anti-HCV therapy with dasabuvir, ombitasvir/paritaprevir/ritonavir and ribavirin at the end of 2016 (Fib-4: 1.62; liver stiffness measured by transient elastography: $7.1 \mathrm{kPa}$; fibrosis stage F2).). The subject displayed rapid HCV RNA abatement (from $22258 \mathrm{cp} / \mathrm{mL}$ to undetectable levels at week 8) as well as a sustained virological response at week 24 (February 2017). CD4+ T-cell numbers showed a slight rise compared to previous years, yet the subject still displays persistent CD4 depletion (latest CD4 T-cell count and $\mathrm{CD} 4 / \mathrm{CD} 8$, respectively, $135 / \mu \mathrm{L}$ and 0.17 ; Fig. 1a, b). Follow-up is currently ongoing and aside from information on the kinetics of CD4+ T-cell counts, it will be interesting to observe the long-term outcome of direct-acting antiviral agents (DAAs) on peripheral T-cell homeostasis and other markers of immune function in the absence of the modulatory effects of pegylatedinterferon- $\alpha[71,72]$.

Finally, microbial translocation has been extensively called upon as a cause for T-cell activation and inadequate CD4+ on cART [73-75], most likely linked to the enduring structural and anatomical defects of the gastrointestinal mucosa [76] as well as skewing of the gut microbiota, thus accounting for impaired local and systemic immunity [76] and hampered CD4+ reconstitution [77, 78]. Our subject displayed higher microbial translocation markers compared to HIV-uninfected controls (lipopolysaccharide: $459 \mathrm{pg} / \mathrm{mL}$ vs $75 \mathrm{pg} / \mathrm{mL}$, IQR $75-79$; soluble CD14: $2.2 \mu \mathrm{g} / \mathrm{L}$ vs $1.9 \mu \mathrm{g} / \mathrm{L}$ IQR $1.4-2.4)$, increased gut permeability parameters (lactulose/mannitole ratio: 0.03 ) and an outgrowth of faecal Bacteroides intestinalis/Bacteroides uniformis; further, exposure of the patient's PBMCs to various Toll-Like Receptor bacterial agonists resulted in a down-regulation of HLA-DR/CD38 co-expression on CD8+ T-cells. These findings suggest $\mathrm{T}$-cell hypo-responsiveness to subclinical endotoxemia in subjects with inadequate $\mathrm{CD} 4+$ recovery $[73,79]$ and may explain why treatment approaches targeting microbial translocation have failed to significantly reduce $\mathrm{CD} 8+\mathrm{T}$-cell activation in this setting [80]. 


\section{Discussion and conclusions}

The present case report highlights the multifactorial origin of poor CD4+ T-cell gain on suppressive antiretroviral therapy thus emphasizing the difficulties of its clinical management. Given that immune failure on effective treatment may still represent a common condition in the future given delayed cART introduction [5] despite current recommendations $[3,4]$, we call for further research on subjects' immune profile [20] and possible causes of chronic antigenic stimulation for the administration of appropriate therapeutic strategies in this setting.

\section{Abbreviations}

CART: Combination antiretroviral therapy; CMV: Cytomegalovirus; DAAs: Direct-acting antiviral agents; HCV: Hepatitis C virus; HIV: Human immunedeficiency virus; IL: Interleukin; IL-7R: IL-7 Receptor; PBMCs: Peripheral blood mononuclear cells; TREC: T-Cell receptor excision circles; Treg: T-regulatory cell; VZV: Varicella Zoster Virus

\section{Acknowledgements}

The authors wish to thank Giusi M. Bellistrì for conducting laboratory experiments, Andrea Gori for helpful advice, the staff and patients at the Clinic of Infectious Diseases, ASST Santi Paolo e Carlo and ASST Fatebenefratelli-Sacco, University of Milan, Italy. We are also grateful to the study patient for agreeing to undergo numerous treatments and procedures as well as believing in clinical research.

\section{Funding}

This work was supported by Gilead Fellowship Program 2012 [grant number F61bd8c044] and the Italian Ministry of Health, Regione Lombardia, grant "Giovani Ricercatori" [number GR-2009-1592029].

\section{Availability of data and materials}

The datasets used and/or analysed during the current study are available from the corresponding author on reasonable request.

\section{Authors' contributions}

CT analyzed the patient data and wrote the manuscript. EM performed the laboratory experiments. AdM supervised clinical management and manuscript preparation. GM designed the clinical studies in which the patient participated, managed the patient and edited the manuscript. All authors read and approved the final manuscript.

\section{Ethics approval and consent to participate}

The ethics committee of the "San Paolo" and "Luigi Sacco" Hospitals in Milan, Italy approved the studies in which the patient and uninfected controls participated. The study subject provided written informed consent to diagnostic procedures and experimental therapeutic interventions. Written informed consent was also obtained from uninfected controls for the study of the IL-7/IL-R system, T-cell homeostasis and microbial translocation.

\section{Consent for publication}

Written Consent for Publication was obtained from the patient.

\section{Competing interests}

The authors declare that they have no competing interests.

\section{Publisher's Note}

Springer Nature remains neutral with regard to jurisdictional claims in published maps and institutional affiliations.
Received: 23 June 2017 Accepted: 26 December 2017

Published online: 05 January 2018

\section{References}

1. Moore RD, Keruly JC. CD4+ cell count 6 years after commencement of highly active antiretroviral therapy in persons with sustained virologic suppression. Clin Infect Dis. 2007;44(3):441-6.

2. Lapadula G, Cozzi-Lepri A, Marchetti G, Antinori A, Chiodera A, Nicastri E, Parruti G, Galli M, Gori A, Monforte A, et al. Risk of clinical progression among patients with immunological nonresponse despite virological suppression after combination antiretroviral treatment. AIDS. 2013;27(5):769-79.

3. Panel on Antiretroviral Guidelines for Adults and Adolescents. Guidelines for the use of antiretroviral agents in HIV-1-infected adults and adolescents. Department of Health and Human Services. 2015.

4. EACS guidelines v.8.0. 2015.

5. Mocroft A, Lundgren J, Antinori A, Monforte A, Brännström J, Bonnet F, Brockmeyer N, Casabona J, Castagna A, Costagliola D, et al. Late presentation for HIV care across Europe: update from the Collaboration of Observational HIV Epidemiological Research Europe (COHERE) study, 2010 to 2013. Euro Surveill. 2015;20(47):30070.

6. Mussini C, Lorenzini P, Cozzi-Lepri A, Lapadula G, Marchetti G, Nicastri E, Cingolani A, Lichtner M, Antinori A, Gori A, et al. CD4/CD8 ratio normalisation and non-AIDS-related events in individuals with HIV who achieve viral load suppression with antiretroviral therapy: an observational cohort study. Lancet HIV. 2015;2(3):e98-106.

7. May MT, Vehreschild JJ, Trickey A, Obel N, Reiss P, Bonnet F, Mary-Krause M, Samji H, Cavassini M, Gill MJ, et al. Mortality according to CD4 count at start of combination antiretroviral therapy among HIV-infected patients followed for up to 15 years after start of treatment: collaborative cohort study. Clin Infect Dis. 2016;62(12):1571-7.

8. Gazzola L, Tincati C, Bellistrì GM, Monforte A, Marchetti G. The absence of CD4+ T cell count recovery despite receipt of virologically suppressive highly active antiretroviral therapy: clinical risk, immunological gaps, and therapeutic options. Clin Infect Dis. 2009;48(3):328-37.

9. Negredo E, Massanella M, Puig J, Pérez-Alvarez N, Gallego-Escuredo JM, Villarroya J, Villarroya F, Moltó J, Santos JR, Clotet B, et al. Nadir CD4 T cell count as predictor and high CD4 T cell intrinsic apoptosis as final mechanism of poor CD4 T cell recovery in virologically suppressed HIV-infected patients: clinical implications. Clin Infect Dis. 2010;50(9):1300-8.

10. Massanella M, Gómez-Mora E, Carrillo J, Curriu M, Ouchi D, Puig J, Negredo E, Cabrera C, Clotet B, Blanco J. Increased ex vivo cell death of central memory CD4 T cells in treated HIV infected individuals with unsatisfactory immune recovery. J Transl Med. 2015;13:230.

11. Bai F, Bellistrì GM, Tincati C, Savoldi A, Pandolfo A, Bini T, Carpani G, Sinigaglia E, Marchetti G, d'Arminio Monforte A. Reduced CD127 expression on peripheral CD4+ T cells impairs immunological recovery in course of suppressive highly active antiretroviral therapy. AIDS. 2010;24(16):2590-3.

12. Bai F, Tincati C, Merlini E, Pacioni C, Sinigaglia E, Carpani G, d'Arminio Monforte A, Marchetti G. Reduced central memory CD4+ T cells and increased T-cell activation characterise treatment-naive patients newly diagnosed at late stage of HIV infection. AIDS Res Treat. 2012;2012:314849.

13. Horta A, Nobrega C, Amorim-Machado P, Coutinho-Teixeira V, Barreira-Silva P, Boavida S, Costa P, Sarmento-Castro R, Castro AG, Correia-Neves M. Poor immune reconstitution in HIV-infected patients associates with high percentage of regulatory CD4+ T cells. PLoS One. 2013;8(2):e57336.

14. Saison J, Maucort Boulch D, Chidiac C, Demaret J, Malcus C, Cotte L, PoitevinLater F, Miailhes $P$, Venet F, Trabaud MA, et al. Increased regulatory T-cell percentage contributes to poor CD4(+) lymphocytes recovery: a 2-year prospective study after introduction of antiretroviral therapy. Open Forum Infect Dis. 2015;2(2):ofv063.

15. Saison J, Ferry T, Demaret J, Maucort Boulch D, Venet F, Perpoint T, Ader F, Icard V, Chidiac C, Monneret G, et al. Association between discordant immunological response to highly active anti-retroviral therapy, regulatory $T$ cell percentage, immune cell activation and very low-level viraemia in HIV-infected patients. Clin Exp Immunol. 2014;176(3):401-9.

16. Piconi S, Trabattoni D, Gori A, Parisotto S, Magni C, Meraviglia P, Bandera A, Capetti A, Rizzardini G, Clerici M. Immune activation, apoptosis, and Treg activity are associated with persistently reduced CD4+ T-cell counts during antiretroviral therapy. AIDS. 2010;24(13):1991-2000.

17. Massanella M, Negredo E, Pérez-Alvarez N, Puig J, Ruiz-Hernández R, Bofill M, Clotet B, Blanco J. CD4 T-cell hyperactivation and susceptibility to cell 
death determine poor CD4 T-cell recovery during suppressive HAART. AIDS. 2010;24(7):959-68.

18. Lederman MM, Calabrese L, Funderburg NT, Clagett B, Medvik K, Bonilla $H$, Gripshover B, Salata RA, Taege A, Lisgaris M, et al. Immunologic failure despite suppressive antiretroviral therapy is related to activation and turnover of memory CD4 cells. J Infect Dis. 2011;204(8):1217-26.

19. Marchetti G, Gazzola L, Trabattoni D, Bai F, Ancona G, Ferraris L, Meroni L, Galli M, Clerici M, Gori A, et al. Skewed T-cell maturation and function in HIV-infected patients failing CD4+ recovery upon long-term virologically suppressive HAART. AIDS. 2010;24(10):1455-60.

20. Pérez-Santiago J, Ouchi D, Urrea V, Carrillo J, Cabrera C, Villà-Freixa J, Puig J, Paredes R, Negredo E, Clotet B, et al. ART-suppressed subjects with low CD4 T-cell counts segregate according to opposite immunological phenotypes. AIDS. 2016;30(15):2275-87.

21. Sainz T, Serrano-Villar S, Díaz L, González Tomé MI, Gurbindo MD, de José MI, Mellado MJ, Ramos JT, Zamora J, Moreno S, et al. The CD4/CD8 ratio as a marker T-cell activation, senescence and activation/exhaustion in treated HIV-infected children and young adults. AIDS. 2013;27(9):1513-6.

22. Serrano-Villar S, Sainz T, Lee SA, Hunt PW, Sinclair E, Shacklett BL, Ferre AL, Hayes TL, Somsouk M, Hsue PY, et al. HIV-infected individuals with low CD4/CD8 ratio despite effective antiretroviral therapy exhibit altered T cell subsets, heightened CD8+ T cell activation, and increased risk of non-AIDS morbidity and mortality. PLoS Pathog. 2014;10(5):e1004078.

23. Carcelain G, Autran B. Immune interventions in HIV infection. Immunol Rev. 2013;254(1):355-71.

24. Marchetti G, Franzetti F, Gori A. Partial immune reconstitution following highly active antiretroviral therapy: can adjuvant interleukin-2 fill the gap? J Antimicrob Chemother. 2005;55(4):401-9.

25. Abrams D, Lévy Y, Losso MH, Babiker A, Collins G, Cooper DA, Darbyshire J, Emery S, Fox L, Gordin F, et al. Interleukin-2 therapy in patients with HIV infection. N Engl J Med. 2009;361(16):1548-59.

26. Weiss L, Letimier FA, Carriere M, Maiella S, Donkova-Petrini V, Targat B, Benecke A, Rogge L, Levy Y. In vivo expansion of naive and activated CD4 +CD25+FOXP3+ regulatory T cell populations in interleukin-2-treated HIV patients. Proc Natl Acad Sci U S A. 2010;107(23):10632-7.

27. Ventevogel MS, Sempowski GD. Thymic rejuvenation and aging. Curr Opin Immunol. 2013;25(4):516-22.

28. Marchetti G, Gori A, Casabianca A, Magnani M, Franzetti F, Clerici M, Perno CF, Monforte A, Galli M, Meroni L. Comparative analysis of T-cell turnover and homeostatic parameters in HIV-infected patients with discordant immune-virological responses to HAART. AIDS. 2006;20(13):1727-36.

29. Vishnu P, Aboulafia DM. Haematological manifestations of human immune deficiency virus infection. Br J Haematol. 2015;171(5):695-709.

30. Bellistrì GM, Casabianca A, Merlini E, Orlandi C, Ferrario G, Meroni L, Galli M, Magnani M, Monforte A, Marchetti G. Increased bone marrow interleukin-7 (IL-7)/IL-7R levels but reduced IL-7 responsiveness in HIV-positive patients lacking CD4+ gain on antiviral therapy. PLoS One. 2010;5(12):e15663.

31. Isgrò A, Leti W, De Santis W, Marziali M, Esposito A, Fimiani C, Luzi G, Pinti M, Cossarizza A, Aiuti F, et al. Altered clonogenic capability and stromal cell function characterize bone marrow of HIV-infected subjects with low CD4+ T cell counts despite viral suppression during HAART. Clin Infect Dis. 2008:46(12):1902-10.

32. Asmuth DM, Pinchuk IV, Wu J, Vargas G, Chen X, Mann S, Albanese A, Ma ZM, Saroufeem R, Melcher GP, et al. Role of intestinal myofibroblasts in HIVassociated intestinal collagen deposition and immune reconstitution following combination antiretroviral therapy. AIDS. 2015;29(8):877-88.

33. Sanchez JL, Hunt PW, Reilly CS, Hatano H, Beilman GJ, Khoruts A, Jasurda JS, Somsouk M, Thorkelson A, Russ S, et al. Lymphoid fibrosis occurs in long-term nonprogressors and persists with antiretroviral therapy but may be reversible with curative interventions. J Infect Dis. 2015;211(7):1068-75.

34. Sieg SF. Interleukin-7 biology in HIV disease and the path to immune reconstitution. Curr HIV Res. 2012;10(4):341-7.

35. Lévy Y, Sereti I, Tambussi G, Routy JP, Lelièvre JD, Delfraissy JF, Molina JM, Fischl M, Goujard C, Rodriguez B, et al. Effects of recombinant human interleukin 7 on T-cell recovery and thymic output in HIV-infected patients receiving antiretroviral therapy: results of a phase $1 /$ /la randomized, placebo-controlled, multicenter study. Clin Infect Dis. 2012;55(2):291-300.

36. Thiébaut R, Jarne A, Routy JP, Sereti I, Fischl M, Ive P, Speck RF, D'Offizi G, Casari $S$, Commenges $D$, et al. Repeated cycles of recombinant human interleukin 7 in HIV-infected patients with low CD4 T-cell reconstitution on antiretroviral therapy: results of 2 phase II multicenter studies. Clin Infect Dis. 2016;62(9):1178-85.
37. Shive CL, Clagett B, McCausland MR, Mudd JC, Funderburg NT, Freeman ML, Younes SA, Ferrari BM, Rodriguez B, McComsey GA, et al. Inflammation perturbs the IL-7 Axis, promoting senescence and exhaustion that broadly characterize immune failure in treated HIV infection. J Acquir Immune Defic Syndr. 2016;71(5):483-92.

38. Hunt PW, Martin JN, Sinclair E, Bredt B, Hagos E, Lampiris H, Deeks SG. T cell activation is associated with lower CD4+ T cell gains in human immunodeficiency virus-infected patients with sustained viral suppression during antiretroviral therapy. J Infect Dis. 2003;187(10):1534-43.

39. Steel A, Cox AE, Shamii MH, John L, Nelson M, Henderson DC, Gotch FM, Gazzard BG, Kelleher P. HIV-1 viral replication below 50 copies/ml in patients on antiretroviral therapy is not associated with CD8+ T-cell activation. Antivir Ther. 2007;12(6):971-5.

40. Mavigner M, Delobel P, Cazabat M, Dubois M, L'faqihi-Olive FE, Raymond S, Pasquier C, Marchou B, Massip P, Izopet J. HIV-1 residual viremia correlates with persistent T-cell activation in poor immunological responders to combination antiretroviral therapy. PLoS One. 2009;4(10):e7658.

41. Tincati C, Merlini E, Braidotti P, Ancona G, Savi F, Tosi D, Borghi E, Callegari ML, Mangiavillano B, Barassi A, et al. Impaired gut junctional complexes feature late-treated individuals with suboptimal CD4+ T-cell recovery upon virologically suppressive combination antiretroviral therapy. AIDS. 2016;30(7):991-1003.

42. Taiwo B, Hunt PW, Gandhi RT, Ellingson A, McKenna M, Jacobson JM, Gripshover B, Bosch RJ. CD8+ T-cell activation in HIV-1-infected patients experiencing transient low-level viremia during antiretroviral therapy. J Acquir Immune Defic Syndr. 2013;63(1):101-4.

43. Chun TW, Murray D, Justement JS, Hallahan CW, Moir S, Kovacs C, Fauci AS. Relationship between residual plasma viremia and the size of HIV proviral DNA reservoirs in infected individuals receiving effective antiretroviral therapy. J Infect Dis. 2011;204(1):135-8.

44. Poizot-Martin I, Faucher O, Obry-Roguet V, Nicolino-Brunet C, RonotBregigeon S, Dignat-George F, Tamalet C. Lack of correlation between the size of HIV proviral DNA reservoir and the level of immune activation in HIV-infected patients with a sustained undetectable HIV viral load for 10 years. J Clin Virol. 2013;57(4):351-5.

45. Hunt PW, Shulman NS, Hayes TL, Dahl V, Somsouk M, Funderburg NT, McLaughlin B, Landay AL, Adeyemi O, Gilman LE, et al. The immunologic effects of maraviroc intensification in treated HIV-infected individuals with incomplete CD4+ T-cell recovery: a randomized trial. Blood. 2013;121(23):4635-46.

46. Rusconi S, Vitiello P, Adorni F, Colella E, Focà E, Capetti A, Meraviglia P, Abeli C, Bonora S, D'Annunzio M, et al. Maraviroc as intensification strategy in HIV-1 positive patients with deficient immunological response: an Italian randomized clinical trial. PLoS One. 2013;8(11):e80157.

47. Wilkin TJ, Lalama CM, McKinnon J, Gandhi RT, Lin N, Landay A, Ribaudo H, Fox L, Currier JS, Mellors JW, et al. A pilot trial of adding maraviroc to suppressive antiretroviral therapy for suboptimal $\mathrm{CD} 4^{+} \mathrm{T}$-cell recovery despite sustained virologic suppression: ACTG A5256. J Infect Dis. 2012;206(4):534-42.

48. van Lelyveld SF, Drylewicz J, Krikke M, Veel EM, Otto SA, Richter C, Soetekouw R, Prins JM, Brinkman K, Mulder JW, et al. Maraviroc intensification of cART in patients with suboptimal immunological recovery: a 48-week, placebo-controlled randomized trial. PLoS One. 2015;10(7):e0132430.

49. Negredo E, Massanella M, Puertas MC, Buzón MJ, Puig J, Pérez-Alvárez N, Pérez-Santiago J, Bonjoch A, Moltó J, Jou A, et al. Early but limited effects of raltegravir intensification on CD4 T cell reconstitution in HIV-infected patients with an immunodiscordant response to antiretroviral therapy. J Antimicrob Chemother. 2013;68(10):2358-62.

50. Massanella M, Negredo E, Puig J, Puertas MC, Buzón MJ, Pérez-Álvarez N, Carrillo J, Clotet B, Martínez-Picado J, Blanco J. Raltegravir intensification shows differing effects on CD8 and CD4 T cells in HIV-infected HAART-suppressed individuals with poor CD4 T-cell recovery. AIDS. 2012;26(18):2285-93.

51. Llibre JM, Buzón MJ, Massanella M, Esteve A, Dahl V, Puertas MC, Domingo P, Gatell JM, Larrouse M, Gutierrez M, et al. Treatment intensification with raltegravir in subjects with sustained HIV-1 viraemia suppression: a randomized 48-week study. Antivir Ther. 2012;17(2):355-64.

52. Chege D, Kovacs C, la Porte C, Ostrowski M, Raboud J, Su D, Kandel G, Brunetta J, Kim CJ, Sheth PM, et al. Effect of raltegravir intensification on HIV proviral DNA in the blood and gut mucosa of men on long-term therapy: a randomized controlled trial. AIDS. 2012;26(2):167-74.

53. Cillo AR, Hilldorfer BB, Lalama CM, McKinnon JE, Coombs RW, Tenorio AR, Fox L, Gandhi RT, Ribaudo H, Currier JS, et al. Virologic and immunologic effects of adding maraviroc to suppressive antiretroviral therapy in individuals with suboptimal CD4+ T-cell recovery. AIDS. 2015;29(16):2121-9. 
54. Vallejo A, Gutierrez C, Hernandez-Novoa B, Diaz L, Madrid N, Abad-Fernandez M, Dronda F, Perez-Elias MJ, Zamora J, Muñoz E, et al. The effect of intensification with raltegravir on the HIV-1 reservoir of latently infected memory CD4 T cells in suppressed patients. AIDS. 2012;26(15):1885-94.

55. Hatano H, Hayes TL, Dahl V, Sinclair E, Lee TH, Hoh R, Lampiris H, Hunt PW, Palmer S, McCune JM, et al. A randomized, controlled trial of raltegravir intensification in antiretroviral-treated, HIV-infected patients with a suboptimal CD4+ T cell response. J Infect Dis. 2011;203(7):960-8.

56. Yukl SA, Shergill AK, McQuaid K, Gianella S, Lampiris H, Hare CB, Pandori M, Sinclair E, Günthard HF, Fischer M et al: Effect of raltegravir-containing intensification on HIV burden and T-cell activation in multiple gut sites of HIV-positive adults on suppressive antiretroviral therapy. AIDS 2010, 24(16): 2451-2460.

57. Buzón MJ, Massanella M, Llibre JM, Esteve A, DahI V, Puertas MC, Gatell JM, Domingo P, Paredes R, Sharkey $M$, et al. HIV-1 replication and immune dynamics are affected by raltegravir intensification of HAART-suppressed subjects. Nat Med. 2010;16(4):460-5.

58. Hatano H, Strain MC, Scherzer R, Bacchetti P, Wentworth D, Hoh R, Martin JN, McCune JM, Neaton JD, Tracy RP, et al. Increase in 2-long terminal repeat circles and decrease in D-dimer after raltegravir intensification in patients with treated HIV infection: a randomized, placebo-controlled trial. J Infect Dis. 2013;208(9):1436-42.

59. Gandhi RT, Coombs RW, Chan ES, Bosch RJ, Zheng L, Margolis DM, Read S, Kallungal B, Chang M, Goecker EA, et al. No effect of raltegravir intensification on viral replication markers in the blood of HIV-1-infected patients receiving antiretroviral therapy. J Acquir Immune Defic Syndr. 2012; 59(3):229-35.

60. Gandhi RT, Zheng L, Bosch RJ, Chan ES, Margolis DM, Read S, Kallungal B, Palmer S, Medvik K, Lederman MM, et al. The effect of raltegravir intensification on low-level residual viremia in HIV-infected patients on antiretroviral therapy: a randomized controlled trial. PLoS Med. 2010;7(8).

61. McMahon D, Jones J, Wiegand A, Gange SJ, Kearney M, Palmer S, McNulty S, Metcalf JA, Acosta E, Rehm C, et al. Short-course raltegravir intensification does not reduce persistent low-level viremia in patients with HIV-1 suppression during receipt of combination antiretroviral therapy. Clin Infect Dis. 2010;50(6):912-9.

62. Appay V, Fastenackels S, Katlama C, Ait-Mohand H, Schneider L, Guihot A, Keller M, Grubeck-Loebenstein B, Simon A, Lambotte O, et al. Old age and anti-cytomegalovirus immunity are associated with altered T-cell reconstitution in HIV-1-infected patients. AIDS. 2011;25(15):1813-22.

63. Freeman ML, Mudd JC, Shive CL, Younes SA, Panigrahi S, Sieg SF, Lee SA, Hunt PW, Calabrese LH, Gianella S, et al. CD8 T-cell expansion and inflammation linked to CMV Coinfection in ART-treated HIV infection. Clin Infect Dis. 2016;62(3):392-6

64. Jacobson MA, Ditmer DP, Sinclair E, Martin JN, Deeks SG, Hunt P, Mocarski ES, Shiboski C. Human herpesvirus replication and abnormal CD8+ T cell activation and low CD4+ T cell counts in antiretroviral-suppressed HIV-infected patients. PLoS One. 2009;4(4):e5277.

65. Hunt PW, Martin JN, Sinclair E, Epling L, Teague J, Jacobson MA, Tracy RP, Corey L, Deeks SG. Valganciclovir reduces T cell activation in HIV-infected individuals with incomplete CD4+ T cell recovery on antiretroviral therapy. J Infect Dis. 2011;203(10):1474-83.

66. Tsiara CG, Nikolopoulos GK, Dimou NL, Bagos PG, Saroglou G, Velonakis E, Hatzakis A. Effect of hepatitis C virus on immunological and virological responses in HIV-infected patients initiating highly active antiretroviral therapy: a meta-analysis. J Viral Hepat. 2013;20(10):715-24.

67. Sajadi MM, Pulijala R, Redfield RR, Talwani R. Chronic immune activation and decreased CD4 cell counts associated with hepatitis C infection in HIV-1 natural viral suppressors. AIDS. 2012;26(15):1879-84.

68. Hodowanec AC, Brady KE, Gao W, Kincaid SL, Plants J, Bahk M, Landay AL, Huhn GD. Characterization of CD4 ${ }^{+} \mathrm{T}$-cell immune activation and interleukin 10 levels among HIV, hepatitis C virus, and HIV/HCV-coinfected patients. J Acquir Immune Defic Syndr. 2013;64(3):232-40.

69. Milazzo L, Foschi A, Mazzali C, Viola A, Ridolfo A, Galli M, Antinori S. Short communication: impact of hepatitis C viral clearance on CD4+ T-lymphocyte course in HIV/HCV-coinfected patients treated with pegylated interferon plus ribavirin. AIDS Res Hum Retrovir. 2012;28(9):989-93.

70. Gonzalez VD, Falconer K, Blom KG, Reichard O, Mørn B, Laursen AL, Weis N, Alaeus A, Sandberg JK. High levels of chronic immune activation in the T-cell compartments of patients coinfected with hepatitis $C$ virus and human immunodeficiency virus type 1 and on highly active antiretroviral therapy are reverted by alpha interferon and ribavirin treatment. J Virol. 2009;83(21):11407-11.

71. Serti E, Chepa-Lotrea X, Kim YJ, Keane M, Fryzek N, Liang TJ, Ghany M, Rehermann B. Successful interferon-free therapy of chronic hepatitis $C$ virus infection normalizes natural killer cell function. Gastroenterology. 2015; 149(1):190-200.e192.

72. Mondelli MU. Direct-acting Antivirals cure innate immunity in chronic hepatitis C. Gastroenterology. 2015;149(1):25-8.

73. Brenchley JM, Price DA, Schacker TW, Asher TE, Silvestri G, Rao S, Kazzaz Z, Bornstein E, Lambotte O, Altmann D, et al. Microbial translocation is a cause of systemic immune activation in chronic HIV infection. Nat Med. 2006; 12(12):1365-71.

74. Jiang W, Lederman MM, Hunt P, Sieg SF, Haley K, Rodriguez B, Landay A, Martin J, Sinclair E, Asher Al, et al. Plasma levels of bacterial DNA correlate with immune activation and the magnitude of immune restoration in persons with antiretroviral-treated HIV infection. J Infect Dis. 2009;199(8):1177-85.

75. Marchetti G, Bellistrì GM, Borghi E, Tincati C, Ferramosca S, La Francesca M, Morace G, Gori A, Monforte AD. Microbial translocation is associated with sustained failure in CD4+ T-cell reconstitution in HIV-infected patients on long-term highly active antiretroviral therapy. AIDS. 2008;22(15):2035-8.

76. Tincati C, Douek DC, Marchetti G. Gut barrier structure, mucosal immunity and intestinal microbiota in the pathogenesis and treatment of HIV infection. AIDS Res Ther. 2016;13:19.

77. Merlini E, Bai F, Bellistrì GM, Tincati C, d'Arminio Monforte A, Marchetti G. Evidence for polymicrobic flora translocating in peripheral blood of HIV-infected patients with poor immune response to antiretroviral therapy. PLoS One. 2011;6(4):e18580.

78. Serrano-Villar S, Rojo D, Martínez-Martínez M, Deusch S, Vázquez-Castellanos JF, Bargiela R, Sainz T, Vera M, Moreno S, Estrada V, et al. Gut bacteria metabolism impacts immune recovery in HIV-infected individuals. EBioMedicine. 2016;8:203-16.

79. Merlini E, Tincati C, Biasin M, Saulle I, Cazzaniga FA, d'Arminio Monforte A, Cappione AJ, Snyder-Cappione J, Clerici M, Marchetti GC. Stimulation of PBMC and Monocyte-derived macrophages via toll-like receptor activates innate immune pathways in HIV-infected patients on virally suppressive combination antiretroviral therapy. Front Immunol. 2016;7:614.

80. Tenorio AR, Chan ES, Bosch RJ, Macatangay BJ, Read SW, Yesmin S, Taiwo B, Margolis DM, Jacobson JM, Landay AL, et al. Rifaximin has a marginal impact on microbial translocation, T-cell activation and inflammation in HIVpositive immune non-responders to antiretroviral therapy - ACTG A5286. J Infect Dis. 2015;211(5):780-90.

\section{Submit your next manuscript to BioMed Central and we will help you at every step:}

- We accept pre-submission inquiries

- Our selector tool helps you to find the most relevant journal

- We provide round the clock customer support

- Convenient online submission

- Thorough peer review

- Inclusion in PubMed and all major indexing services

- Maximum visibility for your research

Submit your manuscript at www.biomedcentral.com/submit
) Biomed Central 